\title{
Students' Attitude towards the Uses of Internet
}

\author{
Dr. Kashif-Ur-Rehman (Corresponding author) \\ Associate Professor, Iqra University Islamabad Campus, Pakistan \\ E-mail: drkashif@iqraisb.edu.pk \\ Ahmed Imran Hunjra \\ MS Scholar, Iqra University Islamabad Campus, Pakistan \\ E-mail: ahmedimran_85@yahoo.com \\ Dr. Nadeem Safwan \\ Assistant Professor, Foundation University Rawalpindi, Pakistan \\ E-mail: nadeemsafwan@yahoo.com
}

Abrar Ahmad

Associate Professor, Iqra University Islamabad Campus, Pakistan

E-mail: abrar@iqraisb.edu.pk

\begin{abstract}
Internet is a useful tool for all in a technologically advanced world. Internet use for education is very important. It is now in practice to teach school to college to get more out of it. In this study, the emphasis is given on the most important success factor that investigates about Internet usage by students of the University, whether it is an effective learning tool for students and teachers and also examines the level of use Internet and whether the Internet is useful for distance learners. The sample of the data is taken from the universities of the twin cities (Islamabad and Rawalpindi). The results reveal that most students find that the Internet knowledge is essential for students and teachers. Above all respondents in the questionnaire that students feel comfortable using the Internet and provides substantial information and half of those surveyed felt that Internet use is difficult in school. Results show that the Internet is easier to use then the collection of research tools, while the Internet is very important. It is recommended that students should align their potential for significant and positive use of the Internet. Further, it is recommended to educate students to use basic Internet tools.
\end{abstract}

Keywords: Technologically advance world, Education purposes, Effective tool, Internet usage

\section{Introduction}

Word Internet is derived from the words "global" and "network". The Internet can be defined as "network of networks and is the world's largest and most widely used network. The Internet can be used as an additional convenient method. The Internet is a useful tool for all in a technologically sophisticated world. The Internet is also widely used in education. The use of Internet for education is very important. It is now being used to teach in schools and colleges to get more out of it (Usun, 2003). The Internet offers more information than the largest libraries in the world. Using the Internet in universities has a positive value. Many universities around the world are also using Internet for educational purposes for easy and effective teaching (Usun, 2003). The Internet has become an essential part in educational institutions since it plays a vital role in meeting information and communication needs of students, teachers and institutions. Teachers are being invited to give their teaching materials and other support resources available through the Internet (Dede, 1996). Students use the Internet to communicate not only with colleagues, but also with their instructors. Students and teachers can communicate with each other with the help of Internet (Chickering \& Gamson, 1991). It has an easy access to all information on the latest research reports from anywhere in the world. It helps researchers, teachers, students and institutions to disseminate information to more viewers worldwide through websites (Molebash, 1999; Wright \& Marsh, 2000). Teachers get useful information about their classes and also download useful and latest information on the subject. A teacher may ask students to find a topic and related research on the Internet. The Internet is also used 
to replace the traditional classroom lecture. The instructor can place course notes on web pages, create recordings video of a live conference for presentation to the Internet or can use combinations of these ideas (Forsyth, 1998).

Although universities have gained valuable resources with the Internet and World Wide Web (WWW) Internet owes much of its magnificent production of the last thirty years to the efforts of these colleges and universities. The Internet also enables various scholars in different places in the world to exchange ideas on various fields of study. Internet has also enabled the growth of distance education, both within nations and without international borders. It is for the benefits that these students, academic institutions and organizations use Internet as an integral part in improving the quality of education (Özgen et al., 1996). The event of the twentieth century is undoubtedly the phenomenon known simply as the Internet or network. The rapid growth of the Internet in 1990 may be recognized by their greater use. Internet use can be seen to support and promote the technological revolution that has taken place in education. The Internet seems to be the most perfect instrument of education that offers students convenience while offering enormous potential for teaching.

The theory of web-based learning is more refined and complex than those of mere learning (Tsai, 2009), Moreover, many students perceived learning in web-based context to have insights and details for the learning perspective. This varies that the implementation of web-based directions may be future prospects for encouraging student's conceptions of learning.

To make proper use of Internet in schools, colleges and universities there is a need to understand the attitudes of students toward the use of it. And it must be ensured that resources are being used in college legally and if there are problems, then problem areas must first strike and then put the necessary measures to overcome the problem. For the student's attitude toward Internet applications, university administration should know that the purposes for which students are using it as entertainment and sports, for academic purposes, correspondence and business and social purposes, etc. It is the duty of the administrator from one university to information and enabling factors that students are using the Internet for educational purposes. Now a day, all schools, colleges and universities are using Internet technology. With the help of this, schools, colleges and universities, teachers are valuable teaching tool. So to have more benefits from the resources you need to know about problem areas or barriers, but also take measures to address the best use of resources as the Internet. Increasingly, universities are investing in Internet services. School is also making its teaching materials available online. While universities and academics are trying to build the Internet, a valuable learning tool, it is necessary to understand what their students' attitudes toward Internet applications. Most of the Pakistani population exists in rural areas where Internet facility is not available and therefore are not aware of the Internet. And institutions are not giving any kind of Internet education to rural areas. As the Internet has become an essential tool for college students and professional life, all things that are occurring are normally made through the Internet. Although Internet students can take many advantages from Internet, but due to some factors, are not aware of the Internet or the information about the Internet is inadequate because the students' attitude toward the Internet is negative or slightly lower. These factors are due to sites that divert the attention of students of the educational purpose for which the student is using the Internet.

This paper focuses all university students frequently using the Internet for study and related work. It explores to know about Internet usage by students of the University whether it is an effective learning tool for students and teachers and also examines the level of Internet use and it usefulness for distance learners.

\section{Literature Review}

The education sector has been an early adopter in the world, continually pushing the capabilities of the network and its applications. Internet has grown from an exclusive environment populated by technophiles and a typical communication tool and information delivery. Internet became a suitable tool to support various activities of universities, ranging from research on teaching of routine administrative tasks (Bell, 2000). In a recent study, "The digital divide: views of Hispanic college students on the educational use of Internet", authors expressed concern about the emergence of a digital divide between majority and minority groups. The researchers surveyed 226 students of first year Hispanic college students enrolled in an intensive course of doctrinal in the southwest, to ask questions about their attitude towards the use of Internet and technology applications. Statistically differences are found between the attitudes of men and women. The differences in attitude are also experimental in terms of their original language. That's one of those who speak English and Spanish at home, the difference found between the first generation and not first-generation college students (Fornell \& Larcker, 1987). Almost all students at various levels have certain experiences of using the Internet. With the wide application of teaching Internet-based learning, these students may have more and richer learning environments based on Internet. 
However, studies on the fundamental nature of student use of Internet have not kept pace with their Internet use (Metzger et al., 2003). Good performance of university students using the Internet in education encourages students to contact teachers, encourage cooperation among students, encourages active learning, gives feedback of time, emphasizes time on task, expectations of positive communication and respects diverse talents and ways of learning (Applebome, 1999).

The USC center used for the Digital Future is a more research focused on. A report based on four years research results in the forgoing outcomes. The report shows that $75 \%$ of Americans has Internet access, the bit of time online improved to an average of 12.5 hours per week versus 6.1 hours in 2000, with e-mail and browsing normal common uses. Primary and secondary students have increased their use of computers in primary and secondary schools, this does not indicate that all college students are next post secondary education with ability or comfort level with computers that improve the use of the Internet as a tool learning (Spennemann, 2006).

A model for virtual classes targeted at developing nations, aims to progress in the development of Internet communications can be used in developing nations to improve the delivery of high quality learning to its citizens submitted by (Amoroso \& Cheney, 1998). Virtual learning environments are seen as having the potential to provide opportunities for active, flexible and individualized learning experiences (Thompson et al., 1991). However, the connection between the learner and the learning environment is fundamental to the understanding of virtual learning environments how to motivate or attract students, especially given the capacity of virtual learning environments to provide more individualized experiences (Igbaria et al., 2000).

The Internet has become such an integral part everywhere and a potent communication tool, it is worth investigating exactly how the Internet fits into the daily lives of staff and students of educational institutions. There is a strong expression of the availability $24 / 7$ on the Internet, i.e., every hour of every day, allows students and scholars for study and research, self-determination of the normal hours of work (Gorman, 2003). The main function of the Internet is used in most conference rooms is an instrument to gather information for teachers and students and has become one of the first places where teachers and students will collect data on almost any subject, whether at home or at school, college or University (Aydn, 2001). There is a lot of training available in the form of texts, primary sources, images, articles, online periodicals, multimedia presentations, books, maps, databases of almost anything you can think of almost any topic. Also, teachers and students are quite competent in the access to this information (Iakushina, 2002; McKenzie, 1998; Shiveley \& VanFossen, 2000). The Internet can be a powerful source for such research, challenging students to investigate problems that are authentic, connected to the curriculum and interdisciplinary areas. The Internet can also help in the presentation and disclosure of the findings of such projects (DeWitt, 2003; Risinger, 1998; Falvo, 1994; Thompson et al., 2004). Finally, the evidence indicates that teachers use the Internet, as it is in their classrooms because the possibilities seem obvious, and they want to be involved with the trend of technology. However, instead of creating a class more interactive and collaborative Internet use every day often leads to an informal teaching style, and indeed can lead students away from reality instead of calling in (Benenson, 2001; Chadwick, 2002).

Technical support, Web experience, task equivocality, and perceived ease of use affect the usage of Internet, significantly (Lee \& Kim, 2009). Technical support and web experience, in turn affect the perceived ease of use. Technical support, task equivocality, and task interdependence are positive related with subjective norm. Teacher Internet self-efficacy and believes about web-based learning are critical determinants of their attitude towards web-based professional development (Pin \& Chung, 2009). The concept which reinforces the positive outcomes of web learning is highly suitable for the favorable attitude towards web-based professional development. The attitude of students and teachers towards using Internet in teaching, using Internet in research and likability of Internet usage in teaching is having a negative correlated with each other (Oral, 2008). Furthermore, the difference between devotion to democracy and qualities of democracy is significant. Likewise, the difference between attitudes towards devotion to democracy is significant with reference to the benefits provided by the Internet.

\section{Method}

\subsection{Sample}

The sample size consisted of three hundred participants, mainly from Islamabad / Rawalpindi, Pakistan, students from various universities in the surrounding region remained as a viable population for the study. Potential respondents were students of Business and Computer Science both men and women aged between 20-33 years. 


\subsection{Instrument and measures}

The scale of 49 items to measure student's attitude towards internet application was developed by Slate et al., (2002) and utilized by Usun (2003) to quantify undergraduate Students Attitudes towards Educational Uses of Internet, but in present study only 17 items were used. These items were most appropriate in present situation. The questionnaire composed of two sections, the first section contained general information about respondents including gender, age, and education. Whereas, the second section related to student's attitude toward Internet applications and had seventeen items. These items were measured on Likert type 5-point scale, where 5 was most degree of agreement and 1 was least degree of agreement. The statistical package social sciences (SPSS) was used for the analyses.

\subsection{Procedure}

The questionnaire was self-administered and distributed among the three hundred respondents. Before giving the questionnaires, all questions were explained to the participants so they can easily complete the questionnaire and the relevant results. Only one questionnaire was given to each respondent. In this questionnaire, respondents were asked about what type of degree they are doing, their age and gender, but also his attitude toward the uses of the Internet. It was difficult to distribute the questionnaire to a large number of respondents due to time constraints, lack of resources and budget. Therefore, convenient sampling method was used.

\section{Results and Discussion}

This section discusses the results of the study and compares those results with earlier work.

\subsection{Results}

\section{Table 1 here}

Table 1 reveals that out of 300 respondents 184 or $61.3 \%$ are male and 116 or $38.7 \%$ are female respectively. The table further shows the age group data. Out of 300 respondents, 212 or $70.7 \%$ are in between $20-23$ years, 48 or $16 \%$ with age bracket $24-27$ years and the remaining 40 or $13.3 \%$ are in between $28-31$ years.

\section{Table 2 Here}

Table 2 demonstrates that out of 300 respondents there are 37 or $12.3 \%$ accounting major whereas 68 or $22.7 \%$ having economics and $17.3 \%$ are interested in finance major, 118 or $39.3 \%$ are pursuing that they are interested in computer major and 25 or $8.3 \%$ respondents are from other business majors. It is evident from the analysis that majority students like computer as major.

\section{Table 3 Here}

The table 3 demonstrates that with respect to, "knowledge of Internet is essential for students", 249 pupils are agreed with the statement, where as 9 are neutral and 42 are disagreed, (Mean=4.03) $(\mathrm{SD}=1.19)$. It is evident from the analysis that majority of the student are towards that knowledge of Internet is essential for students. In the response to "Internet is important as research tools", out of 300 respondents 230 are agreed with the statement, where as 13 are neutral and 57 students are disagreed with the statement. (Mean=3.87) $(\mathrm{SD}=1.29)$. The degree of agreement regarding the third statement that "Internet is easier to use than library", data depicts that 265 students are agreed, 9 are neutral and where as 26 respondents disagreed with the statement, $(\mathrm{Mea}=4.07)$ $(\mathrm{SD}=0.91)$. The table further analyze that with respect to "Internet to be as informative as teachers", 230 participants are agreed with the statement, where as 61 pupils are disagreed with the statement, (Mean=3.85) $(\mathrm{SD}=1.31)$. It is evident from the above analysis that majority of the students find Internet to be as informative as teachers. The statement "Internet have more information in written material", data shows that 65 students are agreed, 19 are neutral, where as 216 respondents disagreed with the statement. (Mean=2.23) $(\mathrm{SD}=1.17)$. The survey of 300 respondents with respect to "I feel overwhelmed when trying to use the Internet for my studies" reveals that 75 participants are agreed with the statement, 12 are neutral and 213 are disagreed with the statement. (Mean=2.28) $(\mathrm{SD}=1.34)$. When asked that, "use of Internet for learning fun", the analysis reveals that 247 subjects are agreed with the statement, 9 are neutral, and where as 44 pupils are disagreed with the statement. (Mean=3.84) $(\mathrm{SD}=1.11)$. So more than two third of respondents are agreed that Internet is used for learning fun. The analysis further shows that, "using the Internet as an integral part of the educational process", majority of respondents i.e. 239 reply positively, where as 9 are neutral and only 52 disagreed with the statement, (Mean=3.84) $(\mathrm{SD}=1.11)$. The degree of agreement regarding the statement, "access the Internet more at university than at home" data shows that out of 300 subjects 229 are agreed with the statement, 6 are neutral, where as 65 students are disagreed. (Mean=3.79) $(\mathrm{SD}=1.28)$. The last statement that, "feel comfortable in using the Internet", majority of subjects i.e. 246 reply positively, where as 9 remain neutral and only 45 respondents 
are disagreed with the statement. (Mean=3.91) $(\mathrm{SD}=1.05)$.

\section{Table 4 Here}

The table 4 reveals that with respect to "Internet contains useless information ", 246 students are disagreed with the statement, where as 16 are neutral and only 38 are agreed, (Mean=1.98) $(\mathrm{SD}=1.06)$. It is evident from the analysis that majority of the student are apposite that Internet contains useless information. In the response to "Internet is difficult to use at school", out of 300 respondents 85 are agreed with the statement, where as 71 are neutral and 144 students are disagreed with the statement. (Mean=2.73) ( $\mathrm{SD}=1.09)$. The degree of agreement regarding the third statement that, "Internet is not important for educational projects", data depicts that 255 students are disagreed, 18 are neutral and where as only 27 respondents agreed with the statement, (Mea=1.93) $(\mathrm{SD}=0.93)$. The table further analyze that with respect to "different about Internet use for education", 170 participants are agreed with the statement, where as 124 pupils are disagreed with the statement, $($ Mean=3.25) $(\mathrm{SD}=1.49)$. When asked that "security concern about using the Internet", the analysis reveals that 218 subjects are disagreed with the statement, 13 are neutral; where as 69 pupils are agreed with the statement. (Mean=2.23) $(\mathrm{SD}=1.25)$. So more than two third of respondents are disagreed that they are security concern about using the Internet. The analysis further shows that, "Internet use at home is slow", majority of respondents i.e.182 reply positively, where as only 8 are neutral and 110 disagreed with the statement, (Mean=3.40) $(\mathrm{SD}=1.40)$. The degree of agreement regarding the statement "accessing, suffering and browsing the Internet confuses me", data shows that out of 300 subjects 229 are disagreed with the statement, 16 are neutral; where as 55 students are agreed. (Mean=2.12) $(\mathrm{SD}=1.14)$.

\subsection{Discussion}

The results of this study are in line with (Slate et al., 2002) and (Usun, 2003) and coincide with remarkable consistencies. In both studies, students agreed strongly that the Internet was as important as other research tools, knowledge of Internet is essential for students and feel comfortable in using the Internet. In this study, the sensitivity of respondents' is more as compared to previous studies. A comparison of Selwyn et al., (2000) results shows that Internet is easier as compared to use of the library, which is the third most popular item, in focus group interviews with 77 students in two UK universities. Selwyn et al (2000) found that, many students did not feel altogether at ease with using the Internet as an educational tool. In contrast, the preset study observed that more than two third students find Internet using easier. Two third (229 out of 300) respondents indicated that they accessed the Internet more at university than at home. A comparison of Gladieux and Swail's (1999) and Selwyn's (1999) results show the same and it is in consistency. Gladieux and Swail (1999) noted that many students only had access to computers in their school. Selwyn (1999) reported that 983 college freshmen and sophomores who had computers at home expressed more favorable attitudes toward using computers in their schoolwork than college students who did not have computers at home. In, Bayram and Uzuncarsilı (1998) administered a field survey to 356 Turkish Internet users. Their results demonstrated that the main problems were related to current hardware, software and cost constraints. Forty-two first year students and 32 second year students reported that they did not keep track of interesting educational sites, but 34 third year and 24 fourth year students answered "yes". In present study almost half of the students find that Internet is difficult to use at school level.

\section{Conclusions and Recommendations}

\subsection{Conclusion}

This research was conducted on the students' attitude toward Internet applications. The research objective is to identify factors influencing student Internet use. Information was gathered through the questionnaires on students using the Internet. The first section concludes that $61.3 \%$ of total respondents are male and $38.7 \%$ are female. It finds that the Internet is an essential knowledge for students and teachers. Mostly the respondents are from computer and economics courses. Students use the Internet primarily for educational and research purposes and benefits instead of playing a positive role and participation in society. However, it provides extensive information on the required assignments, and thus covers many dimensions' that meet educational needs.

Students find the Internet more informative as compared to teachers. The majority of students feel comfortable using the Internet. Above mostly respondents answered that the Internet provides useful information and half of those surveyed felt that Internet use is difficult in school. The 265 or $88.3 \%$ of respondents responded that the Internet is easier to use than the library and is important for educational projects. Respondents enjoy collecting more information than written material. Two third respondents overwhelmed with Internet found in the studies. Additionally, the results indicate that most respondents are satisfied that Internet access is more in college than at home and most of those participants said the Internet is slow at home. Respondents also expressed great 
confidence and satisfaction in using Internet for educational purposes. The 218 or $72.3 \%$ respondents have safety concerns about using the Internet.

It is recommended that students should align their potential for significant and positive use of the Internet. Students must realize that the Internet is a medium. It is recommended that students should not waste their time on useless activities. Basic Internet tools may be introduced to students in their early stages of education. The benefits of Internet should be disseminated to all students. Institutions should provide better infrastructure to facilitate students. Universities should organize courses that build up internal capacity of students require to use Internet in efficient and effective way. The courses organized by University should highlight the use of Internet research techniques and course materials should be situated on the Web to facilitate access by students.

\subsection{Contribution}

As we are living in the era of modern technology, therefore, there must to address the future needs and requirement of students. The future planning is the jurisdiction of policy making institutions and departments such as planning commission, policy institute, etc. The present study will enable future policy makers to provide Internet facilities to future generations. The study reveals that computer and Internet is playing pivotal role in educational projects and especially for research. It is easier to search through internet as compare to sit in the library and collect information. The present study will send a strong message to publishers and writers to shift from their attention from hard binding books to soft copies of their finding and make available on the Internet so that more people can get access to this invaluable information. A wast majority of the student is using Internet in their educational life. This study provides a solution to elderly and handicapped people who can move out from their houses without help. They can use Internet and find interesting things according to their own choice for reading and enjoying. That would help saving time and resources both that is going to be scarce in $21 \mathrm{st}$ millennium. The Internet use will encourage our younger generations to make use of modern technologies to accomplish their ambition. The present study will encourage those students who do not use Internet because of security and reasons to use internet and compete. The study will further contribute to create awareness among older age people who are afraid of both computer and Internet. They should be provided training so that they can also use computer and Internet.

\subsection{Limitations and Future Research}

The present study is conducted in twin cities of Rawalpindi -Islamabad among gradate students of business management and computer faculties, therefore, smaller data collection was possible. Keeping in mind the limitations, convenient sampling method was used. Since $\mathrm{MS} / \mathrm{Ph} . \mathrm{D}$ programs are new in Pakistan and students are engaged in research activities, this sort of study may be conducted at higher level. The present study directs future researcher to explore and address the safety concerns regarding using Internet. The future researchers can find out safe and secure ways so that those who are not using internet can also use. Another important issue in this regard is privacy. The research has shown that privacy is a paramount concern for Internet users. The future researcher can further explore and deal with the privacy issue. The third and last direction for future research is to address misuse of Internet by young students. It is very serious problem and affects both students and parents. Instead of stop using Internet it is the duty of the future researcher and scholars to find out safe and sound ways of using Internet.

\section{References}

Amoroso, D. L., \& Cheney, P. H. (1998). Testing a Causal Model of end-user Environment: an Empirical Investigation. Information and Management, 14, 107-113.

Applebome, P. (1999). Distance learning. [Online] Available: http://www.education.com. Oct 12, 2009 (April 4, 1999)

Aydn, C. H. (2001). Uses of Internet in Turkey, Educational technology research \& development, V 49, Washington. ISSN: 10421629.

Bayram, S., \& Uzuncarsil1. U. (1998). Virtual classrooms on the Web: Problems and solution in Turkey. Conference of the European Educational Research Association, Scottish Council for Research in Education (SCRE) and European Conference on Educational Research, 17-28September, Ljubljana, Slovenia.

Bell, P. (2000). Scientific argument as learning artifacts designing for learning from the Web with KIE, International. Journal of Science Education, 22, 797-817.

Benenson, G. (2001). The unrealized potential of everyday technology as a context for Learning. Journal of Research in Science Teaching, 38, 730-745. 
Chadwick, C. (2002). Why computers are failing in the education of our children. Educational Technology, 42, $35-40$.

Chickering, A.W., \& Gamson, Z. F. (1991). Applying the seven principles for good practice in undergraduate education. New Directions for Teaching and Learning, 47, 63-69.

Dede, C. (1996). Emerging technologies and distributed learning. American Journal of Distance Education, 10, 4-36.

DeWitt, S. (2003). Multicultural democracy and inquiry pedagogy. Intercultural Education, 14, 279-290.

Falvo, D.R., (1994), Effective Patient Education: A guide to increased compliance. (2 ${ }^{\text {nd }}$ ed). An Aspen publication, USA.

Fornell, C., \& Larcker, D. (1987). A Second Generation of Multivariate Analysis: Classification of Methods and Implications for Marketing Research, in Review of Marketing, M. J. Houston (ed.), American Marketing Association, Chicago, 407-450.

Forsyth, I. (1998). Teaching and learning materials and the Internet. (2 ${ }^{\text {nd }}$ Ed.). London: Kogan.

Gladieux, L., \& Swail. (1999). The virtual university and educational opportunities: Issues of equity and access for the next generation. Washington, DC: College Board.

Gorman, L. (2003). Unbounded classrooms: NSW HSC. [Online] Available: http://www.global educator.com.

Iakushina, E.V. (2002). Adolescents on the Internet: A specific charter of information interaction. Russian Education and Society, 44, 81-95.

Igbaria, M., Parasuraman, S., \& Baroudi, J. J. (1996). A motivational model of microcomputer usage. Journal of Management Information Systems, 13, 127-143.

Lee, S \& Kim, B., G (2009). Factors affecting the usage of intranet: A confirmatory study. Computers in Human Behavior, 25(1), 191-201.

McKenzie, J. (1998). Grazing the net: Rising a generation of free-range students. PhiDelta Kappan [Online] Available: http://www.fno.org/text/grazing.html (Sept, 1998).

Metzger, M. J., Flanagin, A. J., \& Zwarun, L. (2003). College student web use, perceptions of information credibility and verification behavior. Computers and Education, 41, 271-290.

Molebash, P. (1999). Technology and education: current and future trends, Information Technology Journal. [Online] Available: http://etext.virginia.edu/journals/itjournal/1999/molebash.html (December 8, 2000)

Oral, B. (2008). The evaluation of the student teachers' attitudes toward Internet and democracy. Computers \& Education, 50(1), 437-445.

Özgen, H., Maraslı, H., \& Yalçın, A. (1996). Türkiye'de uzaktan egitim için uygulanabilir bir model önerisi. A Model Proposal for Distance Education Through Internet in Turkey. First International Distance Education Symposium, 529-535.

Pin, K., C. \& Chung, C., T. (2009). Teachers' attitudes toward web-based professional development, with relation to Internet self-efficacy and beliefs about web-based learning. Computers \& Education, 53(1), 66-73.

Risinger, F. (1998). Global education and the World Wide Web. Social Education, 62, 276-277.

Selwyn, N. (1999). Students' attitudes towards computers in sixteen to nineteen education. Education and Information Technology, 4(2), 129-141.

Selwyn, N., Marriott, N., \& Marriott, P. (2000). Net gains or net pains? Business students' use of the Internet. Higher Education Quarterly, 54(2).

Shiveley, J., \& VanFossen, P. (2000). Using the Internet to create primary source teaching packets. The Social Studies, 91, 244-252.

Slate, J.R., Manuel, M., \& Brinson, JR.K. (2002). The “digital divide": Hispanic college students' views of educational uses of the Internet. Assessment \& Evaluation in Higher Education, 27(1), 75-93.

Spennemann, D. H. R. (2006). The internet and daily life in Australia: an exploration. The Information Society, 22, 101-110.

Thompson, R. L., Higgins, C. A., \& Howell, J. M. (1991). Personal computing: toward a conceptual model of utilization. MIS Quarterly, 15, 125-143. 
Tsai, C., C. (2009). Conceptions of learning versus conceptions of web-based learning: The differences revealed by college students. Computers \& Education, 53(4), 1092-1103.

Usun, S. (2003). Undergraduate Students Attitudes towards Educational Uses of Internet, Interactive Educational Multimedia, 7, 46-62.

Wright, V. H., \& Marsh, G. E. (2000). Technology and teaching: a turning point. [Online] Available: http://computed.coe.wayne.edu/vol5/wright\% 26Marsh.htm (December 12, 2000).

Table 1. Frequency Distribution with respect to "GENDER and AGE" (N=300)

\begin{tabular}{lccccc}
\hline \hline Gender & Frequency & Percentage & Age & Frequency & Percentage \\
\hline Male & 184 & $61.3 \%$ & $20-23$ & 212 & $70.7 \%$ \\
Female & 116 & $38.7 \%$ & $24-27$ & 48 & $16 \%$ \\
& & & $28-31$ & 40 & $13.3 \%$ \\
\multirow{2}{*}{ Total } & 300 & $100 \%$ & Total & 100 & $100 \%$ \\
\hline \hline
\end{tabular}

Table 2. Frequency Distribution and descriptive statistics with respect to "Major" (N=300)

\begin{tabular}{lcc}
\hline \hline Major & Frequency & Percentage \\
\hline Accounting & 37 & $12.3 \%$ \\
Economics & 68 & $22.7 \%$ \\
Finance & 52 & $17.3 \%$ \\
Computer & 118 & $39.3 \%$ \\
Other & 25 & $8.3 \%$ \\
Total & 300 & $100 \%$ \\
\hline \hline
\end{tabular}


Table 3. Descriptive statistics in favor of usage of Internet $(\mathrm{N}=300)$

\begin{tabular}{|c|c|c|c|c|c|c|c|}
\hline \multirow[t]{2}{*}{ Items } & \multicolumn{7}{|c|}{$\begin{array}{l}\text { Frequency Distribution with respect to Students' attitude towards } \\
\text { the uses of internet }(\mathrm{N}=300)\end{array}$} \\
\hline & 5 & 4 & 3 & 2 & 1 & Mean & St. Dev \\
\hline $\begin{array}{l}\text { Knowledge of Internet is essential for } \\
\text { students }\end{array}$ & 127 & 122 & 9 & 18 & 24 & 4.0333 & 1.1904 \\
\hline $\begin{array}{l}\text { Internet is Important like other research } \\
\text { tools }\end{array}$ & 118 & 112 & 13 & 27 & 30 & 3.8700 & 1.2982 \\
\hline Internet is easier to use than library & 91 & 174 & 9 & 17 & 9 & 4.0700 & 0.9099 \\
\hline $\begin{array}{l}\text { I find the Internet to be as informative as } \\
\text { teachers }\end{array}$ & 116 & 114 & 9 & 31 & 30 & 3.8500 & 1.3089 \\
\hline $\begin{array}{l}\text { I enjoy Getting information more from } \\
\text { written material than Internet }\end{array}$ & 11 & 54 & 19 & 124 & 92 & 2.2267 & 1.1718 \\
\hline $\begin{array}{l}\text { I feel overwhelmed using Internet in } \\
\text { studies }\end{array}$ & 28 & 47 & 12 & 106 & 107 & 2.2727 & 1.3389 \\
\hline I use Internet for learning fun & 118 & 129 & 9 & 29 & 15 & 4.0200 & 1.1242 \\
\hline $\begin{array}{l}\text { I find using the Internet as an integral part } \\
\text { of the educational process }\end{array}$ & 81 & 158 & 9 & 37 & 15 & 3.8433 & 1.1058 \\
\hline $\begin{array}{l}\text { I access the Internet more at university than } \\
\text { at home }\end{array}$ & 100 & 129 & 6 & 37 & 28 & 3.7867 & 1.2832 \\
\hline I feel comfortable in using Internet & 83 & 163 & 9 & 33 & 12 & 3.9067 & 1.0496 \\
\hline
\end{tabular}

(5= strongly agree, $4=$ Agree, $3=$ Neutral, $2=$ Disagree, $1=$ strongly disagree $)$

Table 4. Descriptive statistics against usage of Internet $(\mathrm{N}=300)$

\begin{tabular}{|c|c|c|c|c|c|c|c|}
\hline \multirow[t]{2}{*}{ Items } & \multicolumn{7}{|c|}{$\begin{array}{l}\text { Frequency Distribution with respect to Students' attitude towards } \\
\text { the uses of internet }(\mathrm{N}=300)\end{array}$} \\
\hline & 5 & 4 & 3 & 2 & 1 & Mean & St. Dev \\
\hline Internet contains useless information & 11 & 27 & 16 & 136 & 110 & 1.9767 & 1.0550 \\
\hline Internet is difficult to use & 14 & 71 & 71 & 108 & 36 & 2.7300 & 1.0929 \\
\hline $\begin{array}{l}\text { I don't like using internet for important } \\
\text { educational projects }\end{array}$ & 7 & 20 & 18 & 155 & 100 & 1.9300 & 0.9317 \\
\hline $\begin{array}{l}\text { I am different about using internet for } \\
\text { education }\end{array}$ & 80 & 90 & 6 & 73 & 51 & 3.2500 & 1.4950 \\
\hline I have security concern about using internet & 19 & 50 & 13 & 117 & 101 & 2.2300 & 1.2526 \\
\hline I find internet slow at home & 81 & 101 & 8 & 77 & 33 & 3.4000 & 1.3999 \\
\hline $\begin{array}{l}\text { Accessing, suffering and browsing the } \\
\text { internet confuses me }\end{array}$ & 11 & 44 & 16 & 127 & 102 & 2.1167 & 1.1405 \\
\hline
\end{tabular}

(5= strongly agree, $4=$ Agree, $3=$ Neutral, $2=$ Disagree, $1=$ strongly disagree $)$ 


\section{QUESTIONNAIRE}

\section{Students' attitude towards uses of Internet}

\section{Section I}

\section{Respondent profile}
1. Gender?
Male
Female
2. Age?
20-23
24-27
28-31
More than 31

\begin{tabular}{|c|c|c|c|c|}
\hline $\begin{array}{c}\text { Accounting Majors } \\
\text { and Degrees }\end{array}$ & $\begin{array}{c}\text { Economics Majors } \\
\text { and Degrees }\end{array}$ & $\begin{array}{c}\text { Finance Majors } \\
\text { and Degrees }\end{array}$ & $\begin{array}{c}\text { Others Business } \\
\text { Majors and Degrees }\end{array}$ & $\begin{array}{c}\text { All Business Majors } \\
\text { and Degrees }\end{array}$ \\
\hline & & & & \\
\hline
\end{tabular}

3. What is your Major?

\section{Section II}

$($ Strongly Disagree $=1$, Disagree $=2$, Neutral $=3$, Agree $=4$, strongly Agree $=5)$

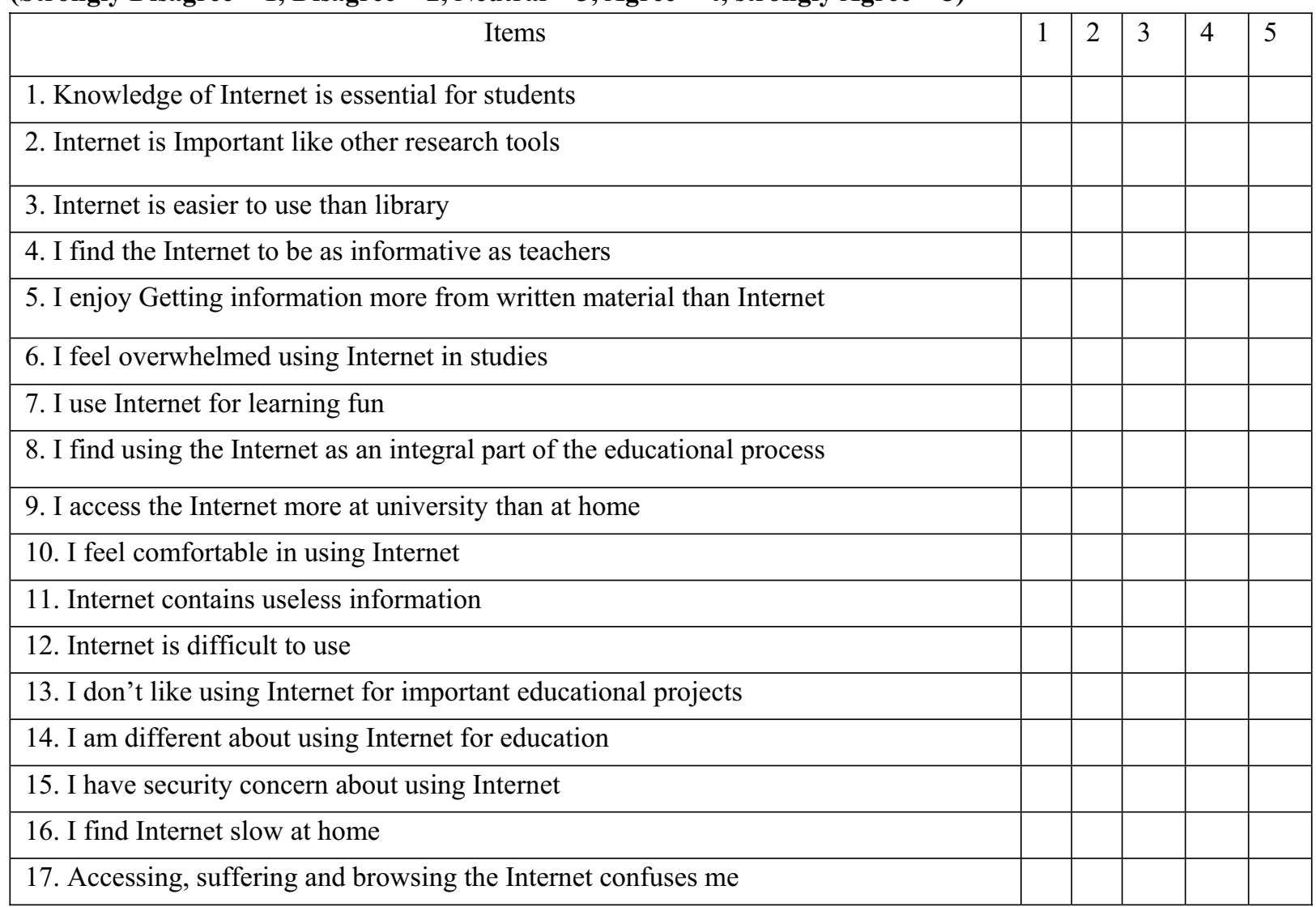

